\title{
Governance and Reform in India
}

\author{
Nirvikar Singh \\ Department of Economics \\ University of California, Santa Cruz \\ Santa Cruz, CA 95064, USA
}

revised July 1996

Phone: (408) 459-4093

Fax: (408) 459-5900

Email: boxjenk@cats.ucsc.edu

An earlier version of this paper was presented at a conference titled "Indian National Economic Policy in an Era of Global Reform: An Assessment", at Cornell University, March 29-30, 1996. I am grateful to the organizers of the conference, particularly Kaushik Basu and Mukul Majumdar. I received extremely helpful comments on my presentation from Atul Kohli, and several other participants, and on earlier drafts from the referees of the journal. I am also grateful to Dilip Mookherjee, Govinda Rao, Donald Wittman and Daniel Friedman for helpful conversations and comments on related work. All of the above are blameless for the considerable shortcomings that no doubt remain. 


\title{
Governance and Reform in India
}

\author{
Nirvikar Singh \\ Department of Economics \\ University of California, Santa Cruz \\ Santa Cruz, CA 95064, USA \\ Phone: (408) 459-4093 \\ Fax: (408) 459-5900 \\ Email: boxjenk@cats.ucsc.edu
}

\begin{abstract}
This paper reviews the background, rationale, and prospects for India's recent reforms in the structures of local government. It begins by commenting on some dimensions of governance, and why it is useful to focus on decentralization, especially in the current Indian context. Then some of the theoretical arguments on federalism as an important mechanism for decentralization, as well as India's overall situation in this dimension, are discussed. India's experience with federalism in general and with local government more particularly, is summarized. The paper focuses particularly on the 1992 constitutional amendments: their history, rationale, and outcomes to date. It also discusses what still needs attention, including complementary institutional reforms in the legal system and judiciary.
\end{abstract}




\title{
Governance and Reform in India
}

\author{
Nirvikar Singh \\ Department of Economics \\ University of California, Santa Cruz
}

\section{Introduction}

Indian economic reform since the 1991 balance of payments crisis has included external liberalization, as well as a freeing up of domestic markets from a variety of government controls. This paper examines a parallel set of reforms that have been taking place in governance in the same period. In particular, I discuss the major initiatives towards decentralization of government that have occurred, their theoretical rationale, their possible outcome, and areas that need attention. While the impetus for these changes in governance has been somewhat independent of the factors that precipitated the current economic reforms, the two sets of reforms are related, both broadly in terms of the general spirit of decentralization of control over economic activity, and more specifically in the area of government finances, which have been of concern from a macroeconomic perspective, and which will be a crucial aspect to ensure the success of the decentralization of governance.

The reforms I refer to are the 73rd and 74th amendments to the Constitution of India, which give local governments, rural and urban, a legal status that they formerly lacked. While the reforms, as embodied in the amendments, are imperfect and incomplete, they mark potentially the most significant step towards decentralization of governance in India, and are possibly the first step towards a more federal structure than has prevailed until now ${ }^{1}$. If these institutional reforms do support the more efficient provision of public goods to the majority of Indians, they will be as significant as the decentralization of the provision of private goods through the relaxation of industrial controls.

At this point, it is useful to explain what I mean by "governance". I shall use this term somewhat broadly, since it seems hard to pin down. Williamson (1994), following Davis and North (1971), for example, distinguishes between the institutional environment ("the set of fundamental political, social, and legal ground rules") and institutions of governance ("arrangements between economic units that govern the ways in which these units can cooperate and/or compete"). I think this distinction is hard to draw in practice. Therefore I prefer the definition of Lewis (1995): "the politics, but, even more, the texture and machinery of government, the bureaucracy, and its interactions with politicians and interests". At the same time, my scope is somewhat narrower than Williamson's definition, in that I will have less to say directly about aspects such as corporate governance or forms of

\footnotetext{
${ }^{1}$ India has sometimes been characterized as only a "quasi-federation": see Verney (1995).
} 
what Williamson calls "private ordering", though I think it will be useful to examine certain kinds of voluntary collective action outside formal government, but impinging on it.

The plan of the paper is as follows. In section 2, I briefly comment on some dimensions of governance, and why it is useful to focus on decentralization, especially in the current Indian context. In section 3, I briefly review some of the theoretical arguments on federalism as an important mechanism for decentralization, as well as India's overall situation in this dimension. This section goes on to summarize India's experience with federalism in general and with local government more particularly. Section 4 examines the attempts to reform the structure of Indian local government, focusing particularly on the 1992 constitutional amendments. I review the history and rationale of the reforms, and what the outcomes have been. In section 5, I discuss what still needs attention, including complementary institutional reforms in the legal system and judiciary. I also comment on the role of nongovernmental organizations. Section 6 returns to the connection between the broader economic reforms and the specific issues considered in the paper, and also provides a brief summary conclusion.

\section{Dimensions of Governance}

From an economist's point of view, the role of government is that of a provider of public goods and corrector of externalities. Even the role of the government as a guarantor of civil and political rights, "valued mainly on noninstrumental grounds" (Elster, 1994, p. 217), has an instrumental component, and we may think of rights or equity as public goods in some sense. As an organizing principle, it is useful to think about governance along three dimensions: (1) the degree of commitment or durability of laws and rules, (2) the degree of enforcement of these laws, and (3) the degree of decentralization of jurisdictions with respect to providing public goods ${ }^{2}$.

\section{Durability}

By their nature, laws are meant to be somewhat durable, that is, to last for some time. In practice, of course, informal social norms may have greater durability. Here I focus on codified laws. Within this category, there are different degrees of durability. Constitutions are obviously meant to be more durable than most laws, being made relatively difficult to amend. Within the particular constitutional framework, more specific laws may be changed more easily, by legislative action. Administrative rules and ordinances are the least durable. The rationale for durability is twofold, involving the usual economist's dichotomy of equity and efficiency. The kind of durability built into constitutions involves both. There are protections of individual and - in the case of India and many other countries - group rights against future attack. This may be justified on ethical grounds, rooted in equity

${ }^{2}$ I introduced this categorization in Singh (1995). It is somewhat arbitrary and incomplete, but, I think, useful. For more complete conceptual discussions, see Williamson (1994), Elster (1994) and the references therein. 
considerations. Provisions to protect property rights, such as requiring government compensation for takings, may be seen as enhancing efficiency by reducing investmentinhibiting uncertainty. In practice, any constitutional aspect can have implications for both equity and efficiency ${ }^{3}$. The efficiency rationale for durability may also be seen in terms of the benefits of precommitment to avoid the problem of "time inconsistency" (Kydland and Prescott, 1977). This term refers to the problem that a government or other economic actor may announce a policy, but then have incentives to modify it once others have responded to the policy. In practice, however, issues of renegotiation imply that the optimal degree of durability is impossible to prescribe in general ${ }^{4}$. Perhaps the only possible, rough generalization is that there should be a tradeoff in practice between specificity of laws and there durability, as measured by the difficulty of changing them. This is the conclusion of Singh (1995), with respect to Indian experience. For protecting individual rights and freedoms, the Indian Constitution seems to have been too easy to amend. But the efficiency consequences of that lack of durability are only indirect, through the effects of conflict ${ }^{5}$. In other contexts, everyday laws and regulations, things have been often too hard to change, owing to the creation of rents, and interests in protecting those rents ${ }^{6}$. This connects the issue of durability to the public choice position of James Buchanan, Gordon Tullock, and others, who stress the need to constrain government in certain ways. Their answer to the problem of Leviathan - large, monopolistic government, unresponsive to constituents - is political competition, both through decentralization, and through effective democracy.

${ }^{3}$ For example, protecting some minority rights may be necessary for their acceptance of the constitution, avoiding either a less efficient country composition without the minority, or the costs of future conflict if minority concerns are ignored. Or, in the case of protections for private property, these may be seen in terms of fairness, and a particular attitude towards the status quo distribution of property.

${ }^{4}$ If all eventualities can be anticipated, then, ex ante, having precommitment will be better than not having it. If, in some eventualities, there will be ex post renegotiation of contracts, laws, rules or agreements, this, too, can be anticipated ex ante. In such cases, some degree of flexibility, by allowing renegotiation, may improve ex post efficiency in some states of the world at the expense of ex ante efficiency. If all eventualities cannot be anticipated, then precommitment is de facto incomplete. For a good discussion of renegotiation in the context of contracting, see Rubinstein and Wolinsky (1992).

${ }^{5}$ However, the more general importance of constitutions as precommitment devices must be recognized: see North and Weingast (1989) and Weingast (1993). A related issue is the question of the nature of the laws that are permitted within the overall framework: see Basu (1992) on the Indian case.

${ }^{6}$ See Bardhan (1984) for an analysis of rent-seeking in India, and Shleifer (1994) and Shleifer and Vishny (1993) for general treatments of corruption and related issues. 


\section{Enforceability}

Laws do not make sense without enforcement. Much recent work has focused on endogenizing enforcement, and analyzing different enforcement mechanisms and institutions. Ultimately, enforcement is the responsibility of the police and judiciary, acting in complementary fashion. The police monitors, investigates and prevents immediate violation where possible. The judiciary examines evidence and it rules on innocence, guilt and punishments. It is this possibility of punishment that acts as a deterrent to violating the law. In practice, in many cases, the police and judiciary do not directly control or enter into the above process. Several examples of alternative enforcement structures exist in India. The most important has been the bureaucracy, which has enforced myriad regulations in the realm of industry and trade, simply by its power to say "no". The police and judiciary remain important, of course, as a back-up, if decisions of administrators are not respected. There has also been a significant overlap between the bureaucracy and the judiciary, in the magistrate's role accorded to members of the Indian Administrative Service. This has been particularly important in rural areas. Also in rural areas, traditional local councils (panchayats) have had some limited judicial authority ${ }^{7}$. The existence of multiple layers and levels of judicial authority is not unique to India, nor are the problems associated with its particular structures: inefficient organization, inconsistent enforcement, and delays. In Singh (1995), I have discussed the workings of the judiciary ${ }^{8}$, police and bureaucracy. The conclusion I reach there is straightforward: more consistent and swifter enforcement of laws in India would have favorable economic consequences. In the case of enforcement, also, one can argue that greater efficiency at the local level would be particularly beneficial, again raising the issue of decentralization.

\section{Decentralization}

One can make a case for decentralization purely on political grounds, that it permits more democratic participation, and increases accountability. Clearly, this argument can not be taken to an extreme, because otherwise there would be no government at all in the conventional sense. The limits are placed by economic criteria of efficiency, particularly the need to take advantage of economies of scale and scope. I will return to issues of efficiency in more detail in the next section. In the European Union this tradeoff between efficiency and democracy is recognized in the principle of subsidiarity, which requires that decisions be taken at the lowest governmental level possible. This makes sense in a stable political environment, with existing national entities within the larger, looser union. Indian history has dictated a somewhat different emphasis. One of the centralizing forces in India at independence in 1947 was the circumstance of partition, and the fear of further conflict and break up. One can see this as an argument on political or economic grounds, for central

${ }^{7}$ Galanter (1989), Chapter 4, examines the judicial role of panchayats and nyaya panchayats in detail. I return to this role in section 3.

${ }^{8}$ On the judiciary, in particular, see Malimath (1990), Mookherjee (1993), and Siwach (1985). 
control to protect people's lives and property at a basic level. Another argument in favor of more centralization in India has been on equity grounds, since the central government can, in theory, be more effective in redistributing income or wealth to each goals of equity.

Decentralizing in India, given its local structures of power, especially at the village level, was typically perceived as inimical to the welfare of the majority. For example, B.R. Ambedkar, one of the chief architects of India's Constitution, made this oft-quoted statement: "What is a village but a sink of localism, a den of ignorance, narrow mindedness and communalism...?" 9

The economic argument for decentralization recognizes the redistributive role of central government, but suggests that diversity of preferences for public goods requires that these be provided at the lowest level possible that is compatible with efficiency of provision, both in terms of costs (economies of scale once again) and demand (allowing for spillover benefits). This approach to decentralization of course focuses on the government's allocative role, as a provider of public goods. The efficiency/diversity argument for decentralization is buttressed by the Tiebout (1956) model, which stresses the benefits of competition among local governments for mobile residents: this competition is lost with centralized government provision of public goods. Recently, Cremer et al (1995) have summarized the possible criticisms of this conventional wisdom on decentralization. They note that centralized government can also provide diversity in the nature and levels of public goods, for example, through local agents, unless it has worse information on preferences than lower level governments. This assumption must then be justified, and becomes the focus of the decentralization argument. They also list the shortcomings of the Tiebout model, including the fact that mobility of residents is often very costly, and that spillovers may be significant (and exacerbated by mobility). Cremer et al go on to outline an incomplete contracts model of decentralization, very much along the lines of the theory of the firm that has been built on the foundation of general principal-agent and bargaining models. One of the important points they make ${ }^{10}$ is that the broad scope of government means that decentralization can have many dimensions. This is an issue that will be especially important in discussing India's reforms decentralizing the polity.

The conclusion is that economic theory does not unequivocally favor decentralization $^{11}$, nor does it necessarily suggest that India has been too centralized. Yet casual empiricism suggests that Indian government has not been effective in providing the basic local amenities, such as drinking water or roads, that local governments are suited to in theory. Some cross-sectional evidence for developing countries suggests that greater

9 See, for example, Dhavan's introduction to Galanter (1989), p. xl.

${ }^{10}$ See also Picciotto (1995).

${ }^{11}$ Bardhan (1995) provides a recent overview of the economics of decentralization in developing countries. See also Tanzi (1995) and Hommes (1995), and the associated comments on their papers, for additional discussion of the issues surrounding decentralization. Olson (1986) is also an important reference. 
decentralization is associated with higher levels of infrastructure spending ${ }^{12}$. Finally, India's size and population growth do seem to favor greater decentralization. India has embarked on potentially major reforms in this dimension, and this alone make decentralization important. Before I turn to these reforms, however, it is useful to provide some further discussion of federalism, that is, the structure within which decentralization is realized.

\section{Federalism and Decentralization: Concepts and India's Experience}

\section{Concepts}

Federalism can be described as the principle of organization of political units under a central authority, but with residuary powers at the decentralized level. Inman and Rubinfeld (1994) identify two federalist dimensions of a constitution: representation of the constituent subordinate units to the central government, and the assignment of governmental tasks to either the central or the lower level governments. Efficient federal institutions can be viewed as having a preferred combination of representation and assignment. Representation in this framework can be measured simply by the number and size of the constituent units of the federation. For example, a greater number of smaller units, all of equal size, say, will increase the degree of representation at the center, since there is greater potential for diversity of choices across units. However, it is important to recognize that representation is a multidimensional concept, and reducing it to one dimension involves some simplification and abstraction $^{13}$.

Whether the potential for greater diversity of choices is realized depends, of course, on the assignment of fiscal functions. The impact of representation also depends on the institutions that govern the central legislature, since this is where much business will be transacted. For example, committee structures, agenda rules, and social norms may affect decisions on levels of public goods or interest group subsidies. Thus the choice of legislative form affects the outcome of any particular combination of representation and assignment. With any legislative form there is a trade-off between increased representation, with its democratic advantages, and economic efficiency, which is impaired by the overspending that accompanies more extensive political representation. The institutional dimension of the assignment of economic tasks to the different levels of government may provide a way of softening this trade-off. How should tasks be assigned? Based on economic efficiency considerations, the brief answer is that where spillovers are significant and/or the goods

${ }^{12}$ See Estache and Sinha (1995). Using a different approach, Davoodi and Zou (1996) suggest that decentralization enhances growth in developing countries if it involves larger local government, but not larger state government.

${ }^{13}$ Another, more difficult issue is that the effective degree of representation - interpreted as the ability to choose different policies - is, to some extent, intertwined with the nature of the assignment of tasks. If policies are effectively decided at the central level, increasing the number of parliamentary constituencies will not have much impact on representation. 
provided are national, the central government should decide, otherwise lower level governments should be assigned the task of provision. However, the extent of spillovers has been contentious in practice. In particular, as Inman and Rubinfeld point out, "If the central legislature assumes responsibility for deciding assignment, then assignment no longer stands as a feasible control to limit legislative inefficiencies." ${ }^{14}$

Given a clear assignment of tasks, a level of representation, and legislative institutions ${ }^{15}$ one can compare the economic efficiency of different combinations of these three institutional variables. Building on the work of Breton and Scott (1978), Inman and Rubinfeld make this comparison based on an assessment of different types of transactions costs, reaching the straightforward conclusion that choosing the level of national public goods should be assigned to the center, while lower level public goods should be provided by state or other lower level governments. However, like the concept of representation, that of assignment is not as straightforward as it might seem. In particular, the existence of intergovernment transfers, particularly with conditions attached, can make de facto assignment different from its ostensible manifestation in the constitution or other law. I therefore discuss assignment in more detail.

The classic treatment of the assignment of expenditure functions was provided by Musgrave (1959), who based his principles for such assignment on his threefold division of the public sector, into allocation, distribution and stabilization branches. He argued that the latter two were the primary responsibility of the center ${ }^{16}$. The "heart of fiscal federalism", according to Musgrave, lies in the allocation branch. The Tiebout model, mentioned in the previous section, is a good illustration of this: individuals shop among different jurisdictions that are themselves optimally created. As noted above, the Tiebout assumptions may fail, and to the extent that they do so, the case for decentralized expenditure is weakened. However, Oates (1991) quotes empirical studies to suggest that the efficiency losses from centralized provision of state or local public goods may be quite high in some practical cases.

The assignment of responsibilities for taxes poses a somewhat different set of issues from the case of expenditure functions. Again, Musgrave (1983) provides a systematic treatment. He suggests that highly progressive taxes (especially for redistribution) and taxes on highly mobile tax bases should be centralized. The logic of this is clear, in terms of

${ }^{14}$ Inman and Rubinfeld (1994), p. 29. They discuss alternative institutions that have been suggested to deal with this problem: a strong executive, locally-run political parties, and public hearings.

${ }^{15}$ Alternatively, as noted by Inman and Rubinfeld, the legislative rules may be undefined by the constitution, in which case they become endogenous functions of the level of representation and nature of assignment.

16 These arguments, and more recent qualifications that have been provided by various writers, are summarized in Oates (1991). 
incentives and efficiency. The central government is also better suited to having authority over those tax bases that are distributed unequally across jurisdictions, for equity as well as efficiency reasons. Finally, benefit taxes such as user charges and fees are very suitable for lower levels of government. In the context of efficiency and incentives, there is a clear connection between the vertical structure of the revenue system and the assignment of fiscal functions. Taxes which distort prices will affect public expenditures ${ }^{17}$. In practice, Musgrave's prescriptions are most clear-cut in comparing national with local governments. This is reflected in empirical experience, cited in Oates (1991). Large, intermediate units such as states and provinces, on the other hand, have features in common with both extreme levels, and tax assignment is also more complex.

The optimal assignment of expenditure functions and tax instruments does not imply that each government at each level must be in balance. Even if we abstract from intertemporal issues in government finance by requiring balance for the public sector as a whole in each time period, individual government units do not have to be in balance. In fact, it is typical for lower level governments to receive transfers from higher level ones. For example, transfers from the center to the state governments are a strong feature of Indian fiscal federalism. A vertical imbalance may arise simply from differing abilities or efficiencies in tax collection. Similar issues arise in the Indian context as well, in that it has been suggested that the central government is less interested in raising tax revenue from sources where the proceeds largely go to the states. In such cases, the practical assignment of tax instruments is not clear-cut.

More generally, intergovernmental grants may be rationalized as serving three main objectives $^{18}$ : subsidization of specific programs where there are spillovers across jurisdictions; greater equity in tax incidence; and equalization of fiscal capacity across subcentral jurisdictions. Conceptually, a designer of a fiscal constitution could optimize social welfare by simultaneously assigning revenue instruments, and expenditure functions, taking account of how individual governments, given this assignment, would maximize the social welfare of their constituents by picking levels of expenditure and taxation and of intergovernmental grants $^{19}$. In practice, the determination of intergovernmental grants, in particular, is often the result of political considerations. Inman (1988) provides evidence for this conclusion for the United States, and Kletzer and Singh (1995) suggest that this is true in India as well. Furthermore, the ability of the central government to make significant categorical grants allows it to substantially affect the direction of lower level government expenditures. Thus, de facto assignment on the expenditure side becomes endogenous, since it is influenced by central government decisions. This discussion indicates that the question of how federal

17 These connections have been explored by Arnott and Grieson (1981) and Gordon (1983), among others. Wildasin (1986) provides an evaluation of this literature.

${ }^{18}$ See, for example, Oates (1991), p. 17, and King (1984), Chapters 3-5.

19 An example of such a conceptual exercise is provided by Gordon (1983). 
structures may best be constructed is basically a question of the optimal degree of decentralization of government. Hence, the reform of local government in India must be examined in the context of India's federal structures. We next discuss India's experience with federalism more closely, particularly with respect to local government.

\section{Indian Federalism and Local-Self Governance}

The theories discussed above provide some guidelines for fiscal federal structures, in terms of representation, and assignment of tax and expenditure functions. The Indian case is one where these guidelines are not well followed. Tax assignments are not clear-cut in India, even without considering the issues of intergovernment tax sharing. The central, state and local governments have overlapping tax assignments which are uncoordinated. Tax rates across commodities are not set at economically rational levels. There are multiple taxes on commodities with cascading effects. Some taxes act as internal tariffs, reducing the advantages of size in India's internal market. These issues have been recognized and analyzed in detail elsewhere, and will not be further examined here ${ }^{20}$. However, I will note that some progress has been made in introducing a value added tax, to overcome some of the problems in the tax structure.

The assignment of expenditure functions has not been subject to criticisms as severe as those on tax assignment, but the vertical fiscal imbalance, where states rely considerably on central transfers, either statutory or discretionary, has been a source of problems. Kletzer and Singh (1995) have emphasized the political economy of central-state fiscal relations, and suggested that the increased use of discretionary transfers permits greater rent-seeking, or, in the terminology of Milgrom and Roberts (1990), increases influence costs within the system. Another effect of the ascendancy of discretion over rules in intergovernment transfers has been the failure to advance equity goals through such transfers ${ }^{21}$, with discretionary transfers counteracting the equalizing effects of formulaic ones made through the Finance Commission $^{22}$. Since equity is a major reason for centralization (internalizing externalities being the other), this is an undesirable aspect of the Indian federal fiscal system. Strengthening the Finance Commission, as suggested by Rao (1995) in his conclusion, would

${ }^{20}$ See Kletzer and Singh (1995) and the references therein.

21 See Rao (1994) for empirical evidence on this point.

${ }^{22}$ The Finance Commission is constituted every five years with a charge to make recommendations that cover a period concurrent to the period of a five year plan. Its membership includes academics as well as civil servants and politicians, but the government selects, and therefore to some extent controls, who serves on each commission. Its existence and broad functions are mandated in the Indian Constitution. Such a constitutional body seems to be unique to the Indian brand of fiscal federalism. The rationale for such an institution can be seen in relation to the Inman-Rubinfeld framework, as providing a way of allowing flexibility in assignment, without making assignment questions politically subservient to the legislature. It seems that the commissions have served some of this role in practice. 
be one possibility. This is in the spirit of the "checks and balances" approach to governance. More specifically, it can reduce the problem of assignment becoming endogenously determined by the center.

While most discussion of Indian fiscal federalism has been at the level of center-state relations, similar issues arise at the level of state-local interactions. Local government institutions are quite varied. Each state is divided into districts, with further subdivisions (tehsils or talukas), for administrative purposes. Each subdivision contains a varying number of villages, which form the base of the panchayat system: village, "block", and district, each with representative councils at that level. Urban municipalities form a separate system, with four grades, based primarily on size ${ }^{23}$. The creation or extension of representative democracy at these decentralized levels in the 1950 Constitution continued a trend begun under the British. However, state governments retained statutory control over all local governments. In practice, this often meant that state governments superseded elected local bodies, and managed local administration directly. I next briefly discuss, in turn, the experience with rural and urban local governments in India.

Efforts by the British to reorganize rural local governments began as early as 1870 , and continued till independence ${ }^{24}$. By 1947, elected panchayats, as a creation of the central government, were common, combining judicial with municipal/administrative functions. As noted above, the Indian Constitution of 1950 emphasized the role of central government. State governments were given extensive responsibilities, but village self-rule was not emphasized in the document, except in Article 40, in the Directive Principles, which requires the government to "take steps to reorganize village panchayats and endow them with such powers and functions as may be necessary to enable them to function as units of selfgovernment". Central and state government initiatives to implement this objective continued throughout the subsequent four decades ${ }^{25}$.

While the central government could form committees and make recommendations, the constitutional structure (Article 246 (3)) requires states to pass legislation regarding local government. The diversity of initial conditions and subsequent experiences led to considerable

${ }^{23}$ More details as well as comparative perspectives may be found in Humes and Martin (1969), pp. 424-432.

${ }^{24}$ A collection of historical material pertaining to such efforts is in Venkatarangaiya and Pattabhiram (1969).

${ }^{25}$ For overviews of this process, see Galanter (1989), Chapter 4; Mathew (1994), Introduction; Desai (1990), Part Two; and Singh and Misra (1993). The last of these provides considerable detail on the various legislation passed by the states throughout this period. 
variation in the institutions of rural local government across the states of India ${ }^{26}$. This makes generalizations difficult, but several broad observations are possible. While direct or indirect elections for the three tiers of rural local government were part of the legal structure, in practice, it was easy and common for state governments to postpone elections or suspend local governing bodies. Another fairly common feature of the panchayat system as it evolved in independent India was the close involvement of politicians from the state level, in particular, Members of the Legislative Assemblies (MLAs). This was in keeping with the dominance and direct control of the state government over the local level. Central and state bureaucrats also exercised considerable control over local decision-making.

A major reason for this lack of effective autonomy of the panchayat structure was the lack of independent fiscal capacity at this level. While rural bodies have had the notional power to tax, and assess fees and penalties, in practice their tax base was severely circumscribed, and they often lacked authority to enforce collection. Thus, funds chiefly came from higher levels of government, with the tiers of local government acting as lobbyists for funds, and conduits for money received. The soft budget constraint (perceived and actual) further reduced incentives for local resource mobilization ${ }^{27}$. This picture fits the view of center-state fiscal relations presented above, without any state level counterpart of the central Finance Commission, making formulaic transfers ${ }^{28}$ as an alternative channel for funds.

While before independence the observation of traditional panchayats suggested that their primary role was as petty courts, with limited administrative functions as providers of public goods, there was a continual effort to incorporate the tiers of rural local governments in the process of development planning and implementation after independence. However, the administrative structures of planning in India tended to reinforce the role of bureaucrats and higher level politicians, at the expense of local government. Of course, standard pork-barrel politics was operational, with powerful MLAs or central Members of Parliament (MPs) able to deliver local amenities to garner votes. The judicial role of panchayats was also given some attention. Since Article 50 of the Constitution requires separation of the judiciary and the executive, an attempt was made, especially after 1959, to create separate nyaya or adalati

26 In addition to the references in the previous footnote, see Bhadouria and Dubey (1989), Kumar and Venkataraman (1974), Shah (1990), and Shiviah and Srivastava (1990). Zink et. al. (1957) provides a dated, but still useful comparison of rural local government in Sweden, Italy and India.

${ }^{27}$ Local revenue collection could be negligible - as little as Re. 1 per capita - even in states such as West Bengal, with a relatively strong commitment to decentralization. See Mathew (1994), p. 222.

${ }^{28}$ There have been one or two exceptions, with states trying to create finance commissions to allocate transfers to lower level governments. A notable example is the report of the Karnataka finance commission (Government of Karnataka, 1989). An earlier example was that of Kerala (Government of Kerala, 1986). 
panchayats (NPs) to handle judicial matters. This would also serve to avoid overburdening panchayat institutions, since they now were expected to perform a wider range of developmental functions. In practice, the NPs saw a decline in their activity, at the same time state courts' workload was rising. Despite the informality and flexibility of procedures in the NPs, there were considerable delays and arrears at that level. This can be attributed to the lack of training of personnel, of institution building in general, and ultimately to a lack of adequate funding of the NPs. Overall, then the NP system came to be seen as a failure, and became effectively moribund ${ }^{29}$.

It is not surprising that rural governance structures have received massive attention in India, given the location of the bulk of its population. However, a considerable amount has also been written on municipal and urban governments ${ }^{30}$. As was the case for rural local governments, municipal or other urban governments in India derived their status and powers solely from state level legislation ${ }^{31}$. Therefore, laws and practice have varied substantially across states, but I will try and summarize some common patterns. As is the case with rural governments, urban governments are relatively restricted in the scope of their activities. In particular, police functions are often effectively controlled at the state level, rather than locally. Unlike rural governments, urban bodies are relatively more fiscally self-reliant. Only about $25 \%$ of their funds came from outside sources, chiefly state grants, in $1979-80^{32}$. However, urban governments have had difficulty in raising revenues from their own sources. Overall, municipal revenues grew much more slowly (at less than half the rate) than did central and state level receipts in the 1960s and 70s.

One of the reasons for difficulty in municipal revenue generation in some states has been the abolition of octroi in those states. Municipal governments in some states traditionally relied very heavily on octroi and other relatively inefficient trade and transport taxes. Octroi provided as much as half of municipal tax revenue in some cases ${ }^{33}$. Property taxes, while significant, have also been subject to problems. A property tax is theoretically

${ }^{29}$ I have relied heavily for this account on Galanter (1989), Chapter 4, which, while written in 1978, seems to be the only detailed analysis of the NP system.

30 Sharma and Kumar (1981) provide an annotated bibliography with over 1,000 items.

${ }^{31}$ In this respect, the legal, though not the practical, situation was not too different from that in the United States. See the discussion in Rao (1992), Chapter 4.

${ }^{32}$ See Rao (1992), Chapter 5, p. 83. Subsequent data in this paragraph is from the same source. See also Dutta (1984), p. 12. Note that there is a wide variation in the financing and other institutional arrangements of municipal governments in India, particularly across states, so any average figures are only suggestive. Useful city case studies may be found in Bhagwan (1983), Dash (1988) and Sachdeva (1991).

${ }^{33}$ See Dutta (1984), Table 1, p. 44. 
the least distortionary for local government, which must be especially sensitive to the mobility of factors. However, municipal authorities have been reluctant to use or enforce such taxes effectively ${ }^{34}$. Some of the problems seem to be managerial, being the use of outdated procedures for assessment and collection of such taxes ${ }^{35}$. One of the consequences of the constraints imposed by lack of effective revenue raising is that, even in prosperous parts of Indian cities, the level of provision of local public goods and services such as water, electricity, garbage collection, and roads is strikingly low. There is also a great deal of inefficiency in provision, though this may not be that different from other cases of monopoly provision. Finally, as is the case with rural governments, state governments have sometimes used their powers to supersede urban bodies, and administer municipalities or cities directly, reducing direct accountability, and effective decentralization.

To summarize, India's experience with local government has been mixed. While there have been repeated efforts to decentralize, particularly in the rural sphere, state and central governments - the latter through the bureaucracy - have retained substantial control of functions. Local governments have had limited fiscal autonomy, and often little incentive to develop fiscal capacity. While federalism at the level of center-state interactions has received considerable attention, decentralization of governance beyond that has been limited in practice. Having said this, it should be noted that local government in India is no worse, and often better than, that in other developing countries: its problems are far from unique.

\section{Reform of Local Government in India}

I briefly outline the genesis of the recent reform of local government, sketch its basic features, and provide an evaluation in terms of the possible positive impacts.

\section{History}

Throughout the period after independence, state and central governments in India appointed a series of committees to examine the functioning of local government, and recommend improvements. In addition, various Finance Commissions made recommendations on this subject. The Central Council of Local Self-Government was created in 1954, under Article 263 of the Constitution, to coordinate urban development issues between the center and states. Rural issues remained separate from urban at the state level, but received even greater attention, and states repeatedly passed legislation dealing with the structures of

${ }^{34}$ See Rao (1992), Chapter 6; Dutta, 1984, Chapter 3.

${ }^{35}$ Paralleling his discussion of the judiciary, Mookherjee (1993) provides an evaluation of India's income tax enforcement procedures, and their current shortcomings. It seems that the problems are as bad at the local level. See Dutta (1984), Ch. 3. Again, it is important to note that there are great regional variations. 
Panchayati Raj. This legislation was often the result of recommendations made by centrally constituted committees.

The genesis of the latest reforms was in the report of the Asoka Mehta committee in 1978. This committee was asked to suggest measures to strengthen Panchayati Raj institutions, allowing them to support more decentralized planning for development. Several states, including West Bengal, Karnataka, and Andhra Pradesh, modified their legislation along the lines of the committee's recommendations, shifting emphasis somewhat from bureaucratic to political control, and generally strengthening rural local government. However, other states continued to have relatively weak Panchayati Raj institutions. Lack of regular elections was a major problem in some states, reducing accountability of local government.

In 1988, another central committee recommended that Panchayati Raj bodies should be given constitutional status. Draft legislation to achieve this had been appended to the Asoka Mehta committee report, and this formed the basis for a constitutional amendment bill introduced in 1989. The motivation for this bill has been called into question, as an attempt to curtail the power of state governments relative to the center. While political considerations no doubt mattered (it would be exceptional if they did not), it is clear from the historical experience that the bill was the culmination of a long series of steps, and the implementation of an ideology that had been evolving since independence. Another criticism of the bill was its imposition of a uniform pattern of local government (for example, three tiers of rural local government) on all the major states, whatever their size, experience, or prevailing institutions. The bill ultimately failed to get the requisite majority in the upper house of parliament.

A new government in 1990 introduced a revised version of the 1989 bill, dealing with municipalities as well as Panchayati Raj institutions. The government fell before it could be discussed in parliament, but the next government pursued the issue. Finally, in 1991, two separate amendment bills were introduced, covering Panchayats and municipalities respectively. These were passed by both houses of parliament towards the end of 1992, ratified by more than half the state assemblies, and brought into force as the 73rd and 74th amendments to the Constitution of India in 1993. These amendments required individual states to pass appropriate legislation, since local government remained a state subject under the constitution, and individual states have proceeded to do so.

\section{Basic features}

What were the key features of the change brought about by the amendments? With regard to rural local governments, the uniformity of the number of tiers, criticized in earlier versions of the bills, was retained, with an exception only for the smallest states, those with populations below 2 million. This imposes a three tier structure (village, intermediate block/taluk, and district) on the larger states, including those such as Kerala, which, after much experimentation and debate, had chosen to have two tiers of local government prior to the amendment. However, this seems to be a relatively minor issue, as will be discussed below. The crucial change is the reduction of state government discretion in the holding of 
elections to local government bodies. Under the new laws, elections to panchayats must be held every five years. Elections to constitute new bodies must be completed before the term expires. If a panchayat is dissolved prematurely, elections must be compulsorily held within six months, the new body to serve out the remainder of the five year term. These provisions will presumably prevent situations such as that in Tamil Nadu, where at one stage panchayat elections were not held for fifteen years, being repeatedly announced and then postponed by successive state governments. With regard to urban local governments, there is a similar strengthening of the electoral requirements, preventing lengthy supersessions of local powers by the state government, and replacing appointed posts with elected ones.

The 73rd amendment gives considerable attention to the nature of elections for the three levels of panchayats. Direct elections are specified for seats at all levels. Seats are reserved for scheduled castes and scheduled tribes in proportion to their population, and offices of chairpersons at all three levels are also reserved in proportion to their population in the state. One third of the seats and of offices of chairpersons are reserved for women. Chairpersons at the intermediate and district levels are to be elected by the panchayat membership, while either direct or indirect elections of chairpersons are permitted at the village level. State level election commissions are to be created to supervise and manage the electoral processes. At the intermediate and district levels, chairpersons of panchayats one level below can be made members, as can MPs, MLAs and MLCs (Members of Legislative Councils).

The act provides for one additional potential avenue of representation and accountability of local government. Each village or group of villages will have a gram sabha, comprising all registered voters in the area. The functions of the gram sabha are left up to the states, and are not further specified, but the Karnataka panchayat act of 1983 provides some indication of how these may function ${ }^{36}$. This act (now, of course, superseded) provided for periodic meetings of gram sabhas, to consider the report of the panchayat, proposals for new programs for village development, implementation of sanitation and drainage schemes through voluntary labor, programs of adult education, and similar issues.

Another vital feature of the reform is its attention to the financial resources of local government. State governments are expected to provide adequate funds for local governments, through grants, the assignment of tax revenues, and authority to collect taxes, tolls and fees. This will not be entirely discretionary, since in each state a finance commission must be established (with five year terms, as is the case with the central finance commission) which will determine the principles for providing local governments with adequate resources. This creation of state level finance commissions is particularly significant, since it has the potential to enhance the independence of local governments. The envisaged structure parallels that of the central finance commission, as well as being similar to the provisions of the Karnataka panchayat act of 1983. States will retain considerable

\footnotetext{
${ }^{36}$ See Singh and Mishra (1993), p. 127.
} 
discretion and control, but the experience at the center-state level suggests that state finance commissions, though advisory in nature, will have an important role. States will also be responsible for making provisions with respect to the maintenance and auditing of lower level government accounts.

Other aspects of the reform include the creation of a new (eleventh) schedule in the Constitution, of 29 subjects (including agriculture, animal husbandry, land and water management, irrigation, roads, education, electricity, and welfare programs) as panchayat responsibilities; specific responsibilities for preparing development plans; the creation of district planning committees to consolidate the plans prepared by panchayats and municipalities; and additional provisions concerning eligibility for and composition of rural local governments. All of these provisions have been debated, and often criticized, in some detail $^{37}$. Below, I will try to evaluate some of the salient issues, drawing on the theoretical discussion of previous sections where possible.

The 74th Amendment, known as the Nagarpalika Act $^{38}$, provides a parallel set of reforms for urban and transitional areas. For areas in transition from rural to urban, nagar panchayats are to be constituted, and, for most purposes, are combined with municipalities. The composition of municipalities remains under the guidelines of the states, subject to the population categories outlined in the amendment $(5,000$ to 10,000 for a nagar panchayat, 10,000 to 20,000 for a municipal council, etc.). A noteworthy feature is the legislative creation of tiers within larger municipalities, in the form of wards and zones, with their own committees. As noted above, a key feature of the legislation is the strengthening of local election procedures, with members at the ward and municipal level being chosen by direct elections. The zonal committees are more of an intermediate level, their composition being the chairpersons of the ward committees in the zone.

Many of the provisions of the Panchayat Act, including composition, reservations, duration, and the role of state finance commissions, are directly applied to municipalities in the Nagarpalika Act. Paralleling the creation of the eleventh schedule in the Constitution, the legislation also creates a twelfth schedule for municipalities, including public health and sanitation, communications, and various welfare services. Law and order are not on this list. Finally, the act requires the constitution of planning committees at the level of districts and metropolitan areas.

\section{Evaluation}

It seems that the strengthening of local government can do two things in the direction of greater decentralization, greater responsiveness to local preferences, and, hence, greater efficiency, despite the argument that it strengthens the center by weakening state government

\footnotetext{
${ }^{37}$ See, for example, Mathew (1994) and Singh (1994).

${ }^{38}$ The text of the 1989 version of the act may be found in Sachdeva (1993), pp. 406-416.
} 
control. First, it provides an easier route for channelling central funds directly to the local level. While this may not seem to get away from the "top-down-ism" decried by some (for example, Lewis,1995), it can have two positive effects, from the Kletzer and Singh (1995) perspective. It reduces the possibility of "skimming" of funds as they pass through multiple levels of politicians and bureaucrats; and, furthermore, the political influence equation is different between the center and a locality, versus the center and a medium-sized or large state: no single locality or district matters politically in the way a large entity such as a state can. Thus two types of rent-seeking might be reduced. In addition, in terms of the Inman and Rubinfeld framework discussed in section 3, a direct responsiveness of the center to local government increases the degree of representation. It is important to note that the latest Finance Commission report (Finance Commission, 1994) already devotes a section to local government finance, and makes recommendations for grants to rural and urban local bodies over the period 1995-2000, in advance of the setting up and functioning of the state finance commissions. Finally, it should be noted that state governments retain considerable power over local government: for example, MLAs can simultaneously be members of panchayats, and states will set the terms of reference for their finance commissions. Thus, the perception of the 73rd and 74th amendments as weakening the states vis-a-vis the center is, in my view, of limited consequence. It may also be noted that the more general economic reforms have increased the power of the states, for example, by freeing them to attract private investment, and reducing central control over the location of industrial activity.

The second positive consequence of stronger local government, one that may be more important from the perspective of genuine decentralization and responsiveness, is that such governments may be able to raise funds more effectively. While there are always potential economies of scale in raising revenue, the Indian fiscal system has been marked by a greater degree of centralization of revenue relative to expenditure than in other federations. At the center-state level, this has meant that states rely heavily on transfers from the central government. This is less true at the state-local level, with $10-25 \%$ of urban local governments' funding coming from grants and other transfers. However, while local governments do not rely heavily on external funding, it has often been noted that the level of services that they provide is quite low on average. Expanding the authority of local governments, by giving them a firmer legal status and more certain terms of office, may help in opening up avenues of raising revenue. This will complement the potentially firmer position of fiscal transfers to local government bodies through the working of state finance commissions $^{39}$. In the long run, and if financial markets continue to develop as one would expect, based on the ongoing and proposed reforms in the financial sector, local authorities may also be able to borrow from the market for capital expenditures. I return to this point in the concluding section.

39 The report of the Karnataka finance commission in 1989 recommended the use of revenue sharing formulas between the state and rural local governments, after noting that the parallel with center-state revenue sharing suffered from the lack of constitutional status of local governments. The amendments remove precisely this sort of objection. 
It is true that expanding fiscal capacity is by itself not sufficient. Fiscal effort also matters. For example, the issues of tax enforcement, of incentives to restructure taxes, and of user charges are extremely important. Will local governments be any better at this than they have been, and better than state governments in the past? Three things should help. First, the firmer political footing for local government should increase accountability to local constituencies. This will increase the pressure to deliver public goods and services more effectively, and to raise the resources to do so. Second, local governments may now have greater freedom to access and manage their funds: even a seemingly small change such as the ability to maintain funds in local banks instead of the state treasury can provide considerably more effective control, and increase the incentive to raise funds ${ }^{40}$. Third, the small size of local constituencies, relative to the size of states, makes it easier to impose hard budget constraints on local governments, forcing them to look to internal sources of funds ${ }^{41}$. None of this is going to be automatic. In section 3, I noted problems in the administration of urban local taxes, both political and managerial: these will take time to overcome. In the case of rural areas, in many cases the panchayats will be starting from scratch in developing revenue sources. Again, this will not be easy, but there are successful examples, such as those presented by Wade (1988), who notes that villages sustain a high level of corporate organization when there are net material benefits to be obtained from such organization. To aid this kind of outcome, several complementary aspects of reform, in addition to political responsiveness and managerial efficiency, will need attention. I address these in the next section

Before turning to what needs to be done, I take a brief look at equity concerns. A major fear since independence has been that pushing decisions below the level of the central or state government would be problematic for equity, in view of the danger of capture of local government by "traditional rural oligarchs" ${ }^{42}$. Not only has this danger lessened over the decades since independence, but in many cases coalitions of such oligarchs at the state government level have been equally problematic. What has helped to reduce this concern at the local level is people's experience of democracy at the national and state levels, where they have realized the power of numbers. The existence of a free press, the spread of the media in general, and explicit efforts by some state governments have also been important in

40 See Government of Karnataka (1989), p. 196. Note that this was a recommendation of the state finance commission, and not a facet of early implementation of the state's 1983 act.

${ }^{41}$ I owe this point to David Wildasin. The recent Tenth Finance Commission, in its report (Finance Commission, 1994, para. 15.13) notes that, "Panchayats and urban local bodies need to have well-defined sources of income and taxing powers. They must be encouraged to exploit them to the full, relying on transfers from above only at the margin...". I think it may be inferred that "at the margin" here means a small relative amount, and not a soft budget constraint.

42 This term is taken from Lewis (1995), p. 201, but the idea has been quite pervasive, often with justification. 
safeguarding the interests of the disadvantaged. Furthermore, there may be genuine possibilities for encompassing coalitions at the local level, particularly where the institutions of democracy shift the balance of power ${ }^{43}$. This has already happened to some extent at the state government level, where coalitions of relatively disadvantaged groups have emerged in some cases. These should provide a check on the problem of inequities at the local, particularly rural, level. Finally, in terms of the provisions of the amendments, if the new state finance commissions use formulas which weight equity in deciding their levels of transfers, this may be at least as good as the existing system of discretionary grants. The discussion of central-state transfers in section 3 noted that discretionary transfers there had tended to counteract the equalizing effects of central Finance Commission transfers. Thus, while India is far from any rural idyll, it does seem that the new decentralized structures need not be inimical to equity.

I close this section with a conceptual remark. The public choice perspective on decentralization (e.g., Brennan and Buchanan, 1980) is that it provides a check on government power through competition among governments. But this is not the only rationale: responsiveness and efficiency may be promoted by decentralization even without this aspect being salient, through an increase in accountability, and an improvement in the incentives of local decision-makers. The strengthening of local government in India has the potential to do this, and this is the aspect I stress here.

\section{What Remains to be Done}

I begin with a discussion of some areas of concern with respect to the reforms as enacted by the center and implemented by the states, specifically in the context of local government as a representative body. Then I turn to issues involving other dimensions of governance, particularly the law and the bureaucracy. Finally, I discuss more broadly the question of governance, including the role of nongovernment organizations (NGOs) and the private sector in the context of the reform of local government.

As I have suggested above, the issues of too much uniformity and too much reduction of state power seem to be relatively unimportant in practice. States have each passed their own legislation to implement the provisions of the constitutional amendments, and in some cases, for example Karnataka, it has been suggested that they have used the occasion to enhance state power at the expense of lower level governments ${ }^{44}$. Karnataka is a particularly striking case, because it had effectively and quite successfully decentralized on its own, prior to the amendments. Several other states are perceived as having been reluctant to devolve

${ }^{43}$ Wade (1988), in discussing the extreme view of Louis Dumont that only dominant castes matter at the panchayat level, notes tellingly that, "Homo hierarchicus has to eat" (p. 179).

${ }^{44}$ See the discussion in Mathew (1994). 
any real power. This may be related to controlling funds from the central government, and rent seeking in general. These initial developments suggest that true decentralization may be a slow process. This was perhaps to be expected: passing laws does not guarantee their implementation or enforcement. However, it remains the case that a constitutional amendment creates a potential that might not exist otherwise: higher level governments have had their discretion reduced by the existence of lower tiers. Just as the Finance Commission has over the years, and despite its weaknesses, provided a rule-bound institutional mechanism for making transfers to state governments, one can anticipate that state finance commissions will also develop in ways that support local government.

Another aspect of the reforms, the ability of MPs and MLAs to be members of some levels of rural local government, also raises some related concerns. It suggests that local government may still remain a political tool of state or central politicians, rather than being responsive to local constituencies. This, too, may not matter in the long run, if local coalitions can outweigh interests of individual politicians. One has seen this process go through cycles at the level of center and state as well. The current situation certainly seems to involve state level coalitions having the balance of power. What will be crucial in possible bargaining situations is who controls what resources. Again, genuine fiscal decentralization will be vital, as stressed by the Tenth Finance Commission in its report.

Turning to the broader scope of governance, another set of potential problems may be the narrow scope of local government as specified in the amendments. While a long list of local government responsibilities has been created in the new Eleventh Schedule of the Constitution, law and order are not among them. This issue came up in discussions of the Karnataka reforms of $1983^{45}$, and the idea of devolving law and order to the district level was mooted, but was completely absent from the constitutional amendments. The discussion there was in terms of the police only, but the same concerns arise with respect to the bureaucracy and the judiciary. Local government cannot mean only increased responsibilities. Adequate financial resources are needed to carry out those responsibilities. To the extent that government provides public goods, and taxes its own constituents to finance that provision to overcome free rider problems, it must have the authority to implement and to enforce. Decentralization of administrative functions without complementary decentralization along other dimensions of governance, particularly enforcement, is less likely to be successful. This includes not just classic law and order (the lathi mentioned in footnote 45) but also tax enforcement and enforcement of contracts.

45 As quoted in Mathew (1994), p. 13, social activist Swami Agnivesh asked, "Who will wield the lathi in the villages? Whose orders will the police take to use force?" The answer then, from Abdul Nazir Sab of Karnataka, was, " It is our intention that the police should come under the control of the zilla parishads. but we cannot do all these things simultaneously. We will do it step-by-step when the district government is constituted." As it turned out, this never happened. 
In section 3, I noted the failure of nyaya panchayats. The lesson from that experience is not that decentralization of judicial processes will not work, but that the existing structures of the judicial components of government must be decentralized with adequate resources provided for its success. The problems of delay and arrears are pervasive at all levels of the Indian judicial system. In the context of the bureaucracy, the incentives of the central and state bureaucrats in their interactions with local government need to be considered more carefully. Clearly, this was not something for constitutional legislation, but it will require the development of new modes of administrative organization, with locally chosen administrators and managers becoming more important. An important issue must be how the central planning apparatus, whose language still permeates the administrative approach in India, and which provided some of the original motivation for the reform of local government (through the desire to have more effective local implementation of centrally conceived economic plans), will adapt to allow local provision of what ought to be local public goods ${ }^{46}$. To some extent, one is tempted to suggest, in the light of the direction taken by economic reforms in trade and industry, that the idea of central planning has outlived its usefulness in India, and local governments should not be shackled by its constraints.

So far, in this paper, I have focused exclusively on the structures of government. Yet self-governance and civil society are ideas with great currency. If I interpret civil society to be the entire gamut of nongovernmental organizations (NGOs) and collective institutions, I do not necessarily see any lack in India. Volunteer organizations, interest groups and social welfare associations seem to be multiplying, alongside and overlapping with traditional occupational and religious groupings or organizations. To some extent, these can be substitutes for lack of effective government: in Delhi, middle class neighborhood residents' associations form to finance and carry out the provision of basic local services such as garbage collection, that are supposed to be performed by local government, but are not, or not effectively. One can view this as an improvement over nothing at all. However, it is important to remember that the rationale of government comes from the publicness of public goods, and the suboptimality of voluntary provision due to free rider problems. Voluntary membership in neighborhood associations at rates of $40 \%$, with minimal dues, may be less efficient than more effective taxation and public provision of some services: economies of scale and scope also matter ${ }^{47}$.

${ }^{46}$ See Bajaj and Sharma (1995) for a discussion of some of the specific problems with the current bureaucratic structures for delivering local public goods and services.

47 The free rider problem is removed if buying a house or apartment requires signing a contract to become a dues paying member of the home-owners association. This has happened with new housing developments in Indian cities, and dues go towards maintaining the complex within well-defined boundaries. Sometimes, however, one steps outside the gate of such a complex into squalor: externalities remain a problem. 
A counter argument may be that if government is ineffective, self-governance is better. This also seems to be the tenor of detailed studies of self-governance in areas such as local irrigation institutions (Ostrom, 1992, Tang, 1992 ). However, even here, it is recognized that such institutions are ultimately feasible only in a system where laws and rules at a broader level are enforced clearly and consistently by government. In a wider perspective, any collective action on a large scale will involve some specialization and delegation of functions. Government is just one aspect of this fact. In a democracy, individuals agree to be ruled by laws made by elected representatives, who are themselves subject to those laws. Voting is only one of several ways that constituent preferences can be articulated. While self-help and voluntary collective action to achieve certain ends are extremely important at the micro level, ultimately, government is the main institution of governance. It must be shaped to serve this role effectively.

The last point is made effectively by Lewis (1995). He describes "pluralism", or "delegating sideways" as a "logical companion theme to decentralization"48, and supports this strongly. He explains these terms as the delegation of authority to agencies outside the official hierarchy, including private enterprises, cooperatives, development corporations, voluntary public associations. He notes the boom in recent years of NGOs, and their frequent virtues, but goes on to point out that "NGOs, whether externally based or indigenous, are often incomplete or awkward substitutes for legitimate official bodies"49. For Lewis, the danger is one of persistent dependence on external benefactors, whether official or not. This brings him back to the need for local self-government. In this context, one may also note that the relative ineffectiveness in India of specific purpose urban authorities - such as housing boards, water supply boards, and pollution control boards ${ }^{50}$ - stems from their lack of incentives and responsiveness, rather than with the concept itself. To return to the analogy with the theory of the firm, discussed in section 2, effective delegation by local governments of specific tasks may make sense, just as a firm may create subsidiaries or divisions to handle specific products.

Lewis's final point in his discussion of this topic is the need for accountability of local government to its citizenry. I would summarize these issues as follows, by relating them to the discussion in previous sections. Effective rules or laws, with a reasonable degree of durability and enforceability, are essential whatever the degree of decentralization of government. Therefore, decentralization must be accompanied by more efficient organization of the primary institutions that make, interpret and enforce laws. Of these, the judicial system may be the immediate place to start. Given a smoothly operating and independent

${ }^{48}$ See Lewis (1995), p. 251.

${ }^{49}$ See Lewis (1995), p. 376. But also see Wade (1988) for a detailed case study on the working of local self-governance structures.

${ }^{50}$ See, for example, Sachdeva (1993), chapter 7. 
judiciary ${ }^{51}$, democracy - which gives constituents the ability to replace their representatives routinely and easily - will be more effective than if it is only a revolving door for opportunism. Accountability requires the law and democracy to work together.

In this framework, the role of NGOs and other nonofficial institutions is twofold. First, any collective group, whether a firm or a volunteer organization, may be engaged in producing something of value, ranging from purely private to purely public goods. For each such institution there are issues of efficient internal organization. These include taking advantage of any economies of scale or scope, having a system of corporate governance, and providing incentives to individual organization members. The second aspect of any such group (and in some cases the primary, or even only role) is its interaction with government in pursuing its goals. This is typically thought of as lobbying. It can be hidden and corrupt, trying to circumvent laws or rules, or it can be open and beneficial, trying to enforce existing laws, or change them to make them better. Political action by consumer or other public groups of the latter form, outside the electoral process is, therefore, an additional means for achieving accountability of government ${ }^{52}$. In this sense, the different forms of collective action are complementary, and reducing the size of constituencies increases representation in this way also, by making it easier for public interest groups to operate.

There is more that can be said about issues of efficient implementation of services that have traditionally been undertaken by the government ${ }^{53}$. The trend in many countries is towards privatizing as much as possible to gain efficiency of delivery and pricing of local public goods. However, where basic needs and equity remain concerns, this course may be undertaken hesitantly, or with some regulation. It may be, however, that even regulated competition is better than local government monopoly provision. Just as the central and the state governments, after economic liberalization, have been able to begin turning to the private sector for the provision of some goods and services, such as telecommunications and electricity, local governments, once they are established as credible entities, may be able to contract out local functions, such as sanitation, where benefits are local and user fees can be collected, to private organizations. Again, these kinds of developments are not automatic, but the creation of independent local bodies creates the potential for them to take place, and for decisions about what to contract out to be taken more efficiently.

${ }^{51}$ It is important to note that there are many positive examples in India of both these characteristics: here I am arguing for the kind of environment that would make these routine.

52 At the same time, issues of accountability and responsiveness arise for nonofficial bodies as well. I think this is what makes government the key aspect of governance, and resolves the potential "chicken and egg" problem - do we need effective nongovernmental action to ensure a responsive and efficient government?

${ }^{53}$ See, for example, Bajaj and Sharma (1995) and Dillinger (1995). 


\section{Conclusion}

Reform of local government in India has had a different impetus and history than the changes put in motion by the 1991 balance of payments crisis. However, they are closely connected by the issue of reducing fiscal deficits, and the management of government finances in general. This connection may not be positive. For example, it is now well recognized that the structure of fiscal federalism in India has contributed to the overall problem of government deficits ${ }^{54}$. The states, used to operating with soft budget constraints, have seen their finances deteriorate, and the post-reform squeeze has tended to reduce their spending on social and economic services such as education and health ${ }^{55}$. In this climate, there are real concerns about the fiscal impact of local government reform. For example, the recent World Bank country study, in discussing tax reform, tax sharing and the disincentives for lower level resource mobilization, offers the following caution:

The 73rd Amendment...is an important and welcome change, aimed at increasing the autonomy of local governments. However, it may accentuate fiscal indiscipline by establishing between states and local governments a system of transfers similar to the one in place between the central and state governments.

Related concerns, that the center will ultimately have to channel resources to local governments, directly and through the states, are expressed in the Tenth Finance Commission report (Finance Commission, 1994, Chapters 10 and 15).

While there is a danger of increased fiscal deficits as a result of decentralization (something of that nature occurred in Brazil, for example), I think the Indian case offers some positive prospects, for the following reasons. First, the decentralization is down to the local level, unlike the Brazilian case, which gave the states more fiscal autonomy. As noted earlier, smaller constituencies make it easier to impose hard budget constraints ${ }^{56}$. Second, the quote from the World Bank seems to neglect the fact that the central Finance Commission has done a relatively good job, within its constraints: greater problems have arisen with more discretionary transfers, including categorical grants and loans. This has been the only system operating between the state and local levels. The creation of state finance commissions has the potential to reduce such discretionary transfers from the states to local governments, and

54 See Kletzer and Singh (1995) for a conceptual analysis, and World Bank (1995) for recent data.

${ }^{55}$ See ,for example, World Bank (1995), p. 34.

${ }^{56}$ In contrast, India's states are big enough to have considerable clout at the center. For example, the chief minister of Andhra Pradesh, a key supporter of the new coalition central government, is seeking a bailout to pay for state level subsidies and tax revenue losses (Waldman, 1996). 
to increase the transparency and efficiency of such transfers ${ }^{57}$. My conclusion is that the reform of local government may actually support the goal of reducing overall government deficits.

While making intergovernment transfers more efficient will help, raising resources more effectively is crucial. Here also, the broader set of reforms may turn out to be complementary to the reform of local government. One may think of the underlying goal of economic reforms in India as the achievement of a more efficient use of capital, to support higher growth. Reforms of trade, industry and financial markets are all, in some way, driven by this basic objective. Relying on smoothly functioning (and well-regulated) financial markets to allocate capital, in this view, is crucial for government as well as for the private sector. Historically, state and local governments have not been able to engage in market borrowings. Instead, they have relied on trickle-down funding through the central planning process, which has often not been responsive to the wants of local residents. Since many municipal service projects involve long-lasting capital and equipment, the building up of local capital has been hindered ${ }^{58}$. The creation of urban local governments with independent status, legal authority and regularly elected officials, raises the possibility that local governments may eventually be able to borrow money in the financial markets for local sanitation, roads and schools. For this to work, of course, hard budget constraints must exist: state governments must not too easily bail out municipalities in trouble. Clearly, this development will take time, but it should be noted that the central government has taken the first steps towards market borrowing itself, representing a major break with past practice ${ }^{59}$.

Ultimately, of course, the question is whether decentralization will permit the more efficient use of the funds now to be put in the hands of local governments. Greater responsiveness to constituents as a result of democratic decentralization should certainly help. But it will also require the transfer of existing staff from central and state government to local

${ }^{57}$ In the same section, the World Bank report points out the incentive problems created by the particular tax sharing formulas used up to now between the center and the states. It is worth noting that central Finance Commissions have been proposing effective alternatives for tax sharing (Finance Commission, 1994, Chapter 13). There is no reason state finance commissions cannot follow such models.

${ }^{58}$ See, for example, the discussion in Rao (1986), Chapter 9. Again, the Karnataka state finance commission made a prescient recommendation on this issue, that local authorities should be permitted to create income earning assets and set up enterprises through bank loans. I would disagree, however, with their suggestion that these loans should be guaranteed by the state government. That would clearly create a severe incentive problem.

${ }^{59}$ World Bank (1995), pp. 49-50. 
government, and the reorganization of administration at all levels ${ }^{60}$. This is among the complementary reforms that still await attention.

This paper has attempted to examine recent Indian reforms, which provide local governments with a constitutional and legal status they had previously lacked, in the context of issues of governance, decentralization, and federalism more generally. These reforms have the potential to lead to changes that will be as significant as the deregulation of the private sector in India. However, decentralization as conceived and implemented so far will not be enough, without attention to the other aspects of governance highlighted in this paper. Decentralization of authority and enforceability of laws are complementary aspects of governance. Therefore, the functioning of the judiciary, bureaucracy and police at the local level particularly deserve attention. Creating effective local governmental and judicial structures, with an efficient assignment of tasks, and the power to raise resources and enforce laws at the local level, is likely to make a significant difference to India's economic performance.

${ }^{60}$ Again, see Finance Commission (1994, Chapter 10), and Bajaj and Sharma (1995). 


\section{References}

Arnott, R., and R. E. Grieson (1981), "Optimal Fiscal Policy for a State or Local Government", Journal of Urban Economics, 23-48.

Bajaj, J.L., and Rita Sharma (1995), "Improving Government Delivery Systems: Some Issues and Prospects", Economic and Political Weekly, May 27, M73-M80.

Bardhan, Pranab (1995), "The Economics of Decentralization in Less Developed Countries", processed, UC Berkeley, Department of Economics.

Bardhan, Pranab (1984), The Political Economy of Development in India, Oxford: Basil Blackwell.

Basu, Kaushik (1992), "Markets, Laws and Governments", in B. Jalan (ed.), The Indian Economy: Problems and Prospects, Delhi: Viking Publishers.

Bhadouria, B.P.S., and V.B. Dubey (1989), Panchayati Raj and Rural Development, New Delhi: Commonwealth Publishers.

Bhagwan, Jai (1983), Municipal Finance in the Metropolitan Cities of India: A Case Study of Delhi Municipal Corporation, New Delhi: Concept Publishing.

Brennan, Geoffrey, and James M. Buchanan (1980), The Power to Tax: Analytical Foundations of a Fiscal Constitution, Cambridge: Cambridge University Press.

Breton, A., and A. Scott (1978), The Economic Constitution of Federal States, Toronto: Toronto University Press.

Crémer, Jacques, Antonio Estache and Paul Seabright (1995), "The Decentralization of Public Services: Lessons From the Theory of the Firm", in Decentralizing Infrastructure: Advantages and Limitations, ed., Antonio Estache, World Bank Discussion Paper 290.

Dash, Gokulananda, Municipal Finance in India: Based on Orissa, New Delhi: Concept Publishing.

Datta, Abhijit, Municipal Finances in India, New Delhi: Indian Institute of Public Administration, 1984.

Davis Lance E., and Douglass C. North (1971), Institutional Change and American Economic Growth, Cambridge: Cambridge University Press. 
Davoodi, Hamid, and Heng-fu Zou (1996), "The Effects of Fiscal Decentralization on Economic Growth: A Cross-Country Study", Policy Research Department, The World Bank, March.

Desai, Vasant (1990), Panchayati Raj: Power to the People, Bombay: Himalaya Publishing House.

Dillinger, William (1994), Decentralization and Its Implications for Urban Service Delivery, UNDP/UNCHS/World Bank Urban Management Programme Discussion Paper 16.

Elster, Jon (1994), "The Impact of Constitutions on Economic Performance", Proceedings of the World Bank Annual Conference on Development Economics, 209-226.

Estache, Antonio, and Sarbajit Sinha, "Does Decentralization Increase Public Infrastructure Expenditure?", in Decentralizing Infrastructure: Advantages and Limitations, ed., Antonio Estache, World Bank Discussion Paper 290.

Finance Commission (1994), Report for 1995-2000, Government of India: New Delhi.

Galanter, Marc (1989), Law and Society in Modern India, Delhi: Oxford University Press.

Gordon, Richard H. (1983), "An Optimal Taxation Approach to Fiscal Federalism", Quarterly Journal of Economics, 567-586.

Government of Karnataka (1989), Report of the Finance Commission for Zilla Parishads and Mandal Panchayats, Bangalore: Govt. of Karnataka.

Government of Kerala (1986), Report of the Panchayat Finance Commission, Trivandrum: Govt. of Kerala .

Hommes, Rudolf (1995), "Conflicts and Dilemmas of Decentralization , Annual World Bank Conference on Development Economics 1995, pp. 331-350.

Humes, Samuel and Eileen Martin (1969), The Structure of Local Government, The Hague: International Union of Local Authorities.

Inman, Robert P. (1988), "Federal Assistance and Local Services in the United States: The Evolution of a New Fiscal Order", in H. Rosen (ed.), Fiscal Federalism: Quantitative Studies, Chicago: University of Chicago Press.

Inman, Robert P., and Daniel L. Rubinfeld (1994), "The Political Economy of Federalism", processed, University of California at Berkeley and University of Pennsylvania, June . 
King, D.N. (1984), Fiscal Tiers: The Economics of Multi-Level Government, London: George Allen \& Unwin.

Kletzer, Kenneth and Nirvikar Singh (1995), "The Political Economy of Indian Fiscal Federalism", forthcoming, Sudipto Mundle (ed.), Fiscal Policy in India, New Delhi: Oxford University Press.

Kumar, Sushil, and K. Venkataraman (1974), State-Panchayati Raj Relations: A Study of Supervision and Control in Tamil Nadu, New York: Asia Publishing House.

Kydland, Finn, and Edward Prescott (1977), "Rules Rather than Discretion: The Inconsistency of Optimal Plans", Journal of Political Economy, 85, 473-491.

Lewis, John P. (1995), India's Political Economy: Governance and Reform, Delhi: Oxford University Press.

Malimath, V.R. (1990), Report of the Arrears Committee 1989-90, headed by Justice V.R. Malimath, Supreme Court, Government of India.

Mathew George (1994), ed., Status of Panchayati Raj in the States of India, 1994, Institute of Social Sciences, New Delhi: Concept Publishing Company.

Milgrom, P., and J. Roberts (1990), "Bargaining Costs, Influence Costs, and the Organization of Economic Activity", in J. Alt and K. Shepsle, eds., Perspectives on Positive Political Economy, Cambridge: Cambridge University Press.

Mookherjee, Dilip (1993), "Redefining the Economic Role of the State: The Role of 'Positive' and 'Negative' Institutional Reforms in India", paper presented at conference on Economic Liberalization in South Asia, University of California, Berkeley, April.

Musgrave, R.A., The Theory of Public Finance, New York: McGraw Hill, 1959.

Musgrave, R.A., "Who Should Tax, Where and What?", in C. McLure, ed., Tax Assignment in Federal Countries, Canberra: Australian National University Press, 1983, 2-19.

North, Douglass C., and Barry Weingast (1989), "Constitutions and Commitment: The Evolution of Institutions Governing Public Choice in Seventeenth-Century England: Journal of Economic History, 49, 803-832.

Oates, W. (1991), "Principles of Fiscal Federalism: A Survey of Recent Theoretical and Empirical Research", IRIS Working Paper No. 21, University of Maryland, College Park.

Olson, M., "Toward a More General Theory of Governmental Structure", American Economic Review, May 1986. 
Olson, M., The Logic of Collective Action, Cambridge, Mass.: Harvard University Press, 1971.

Ostrom, Elinor (1992), Crafting Institutions for Self-Governing Irrigation Systems, San Francisco: Institute for Contemporary Studies Press.

Picciotto, Robert (1995), Putting Institutional Economics to Work, World Bank Discussion Paper 304.

Rao, M. Govinda (1995), "Fiscal Federalism in India: Problems and Prospects", forthcoming, Sudipto Mundle (ed.), Fiscal Policy in India, New Delhi: Oxford University Press.

Rao, M. Govinda (1994), "Intergovernment Transfers in India", processed, paper presented at Conference on Fiscal Transfer Systems, Qingdao, China, July 25-29.

Rao, N. Rajagopala (1986), Municipal Finances in India (Theory and Practice), New Delhi: Inter-India Publications.

Rubinstein, Ariel, and Asher Wolinsky (1992), "Renegotiation-Proof Implementation and Time Preferences", American Economic Review, 82, 600-614.

Sachdeva, Pardeep (1991), Dynamics of Municipal Government and Politics in India, Allahabad: Kitab Mahal.

Sachdeva, Pardeep (1993), Urban Local Government and Administration in India, Allahabad: Kitab Mahal.

Shah, B.L. (1990), The Role of Panchayats in Integrated Rural Development, New Delhi: Cosmo Publications.

Sharma, R.N., and Devendra Kumar (1981), Municipal Government in India: An Annotated Bibliography, New Delhi: Indian Institute of Public Administration.

Shiviah M., and K.B. Srivastava (1990), Factors Affecting Development of the Panchayati Raj System, Hyderabad: National Institute of Rural Development.

Shleifer, Andrei (1994), "Establishing Property Rights", Proceedings of the World Bank A nnual Conference on Development Economics, 93-117.

Shleifer, Andrei and Robert Vishny (1993), "Corruption", Quarterly Journal of Economics, $108,599-617$.

Singh, Hoshiar (1994), "Constitutional Base for Panchayati Raj in India: The 73rd Amendment Act", A sian Survey, 34, 7, July, 818-827. 
Singh, Nirvikar (1995), "The Economic Consequences of India's Institutions of Governance", paper presented at International Conference on Law and Economics, New Delhi, India, January 11-13, 1996.

Singh, S.S. and Suresh Misra (1993), Legislative Framework of Panchayati Raj in India, New Delhi: Intellectual Publishing House.

Sivaraman B. (1991), Bitter Sweet: Governance of India in Transition, New Delhi: Ashish Publishing House.

Siwach, J.R. (1985), Dynamics of Indian Government and Politics, New Delhi: Sterling Publishers.

Tang, Shui Yan (1992), Institutions and Collective Action: Self-Governance in Irrigation, San Francisco: Institute for Contemporary Studies Press.

Tanzi, Vito (1995), "Fiscal Federalism and Decentralization: A Review of Some Efficiency and Macroeconomic Aspects", Annual World Bank Conference on Development Economics 1995, pp. 295-316.

Tiebout, C. (1956), "A Pure Theory of Local Expenditures", Journal of Political Economy, 416-424.

Venkatarangaiya, M., and M. Pattabhiram (1969), Local Government in India: Select Readings, Calcutta: Allied Publishers.

Verney, Douglas V. (1995), "Federalism, Federative Systems, and Federations: The United States, Canada, and India", Publius, Spring, pp. 81-97.

Wade, Robert (1988), Village Republics: Economic Conditions for Collective Action in South India, Cambridge: Cambridge University Press.

Waldman, Peter (1996), "India's States Poised to Grab More Power: Wobbly New Ruling Coalition Needs Regional Support", The Wall Street Journal, May 30.

Weingast, Barry (1993), "Constitutions as Governance Structures", Journal of Institutional and Theoretical Economics, 149, 233-261.

Wildasin, D.E., Urban Public Finance, New York: Harwood Academic Publishers, 1986.

Williamson, Oliver (1994), "The Institutions and Governance of Economic Development and Reform", Proceedings of the World Bank A nnual Conference on Development Economics, 171-197. 
World Bank (1995), India: Recent Economic Developments and Prospects, Washington, D.C.: The World Bank.

Zink, Harold, Arne Wählstrand, Feliciano Benvenuti and R. Bhaskaran (1957), Rural Local Government in Sweden, Italy and India: A Comparative Study, London: Stevens \& Sons. 